\title{
Combining Ability and Heterosis for Earliness, Yield and Its Component Traits in Okra (Abelmoschus esculentus L. Moench)
}

\author{
R. Eswaran* and V. Anbanandan \\ Department of Genetics and Plant Breeding, Faculty of Agriculture, Annamalai University, \\ Annamalai Nagar, Tamil Nadu, India \\ *Corresponding author
}

\section{A B S T R A C T}

\begin{tabular}{|l|}
\hline K e y w o r d s \\
Okra, Mean \\
performance, \\
Combining ability, \\
Heterosis
\end{tabular}

\section{Introduction}

Okra [Abelmoschus esculentus (L.) Moench], is an important vegetable crop grown in the tropical, sub-tropical regions of Asia, Africa, America and the temperate regions of Mediterranean region.

In India, it is commercially grown in Gujarat, Maharashtra, Andhra Pradesh, Uttar Pradesh, Tamil Nadu, Karnataka and Punjab. In India, it is grown is 4.98 lakh hectares with the annual production of about 57.84 lakh tones (Indian Horticulture Database - 2011) and it is the second leading producer of vegetable in the world.
Combining ability analysis was carried out for earliness, fruit yield and its related traits in okra in a $6 \times 6$ full diallel fashion. Both general combining ability (GCA) and specific combining ability (SCA) variances are highly significant for all the characters indicating the importance of additive and non-additive gene actions. The highest significant negative GCA effect for earliness were recorded by the parents Arka Anamika, Parbhani kranti and for fruit yield per plant the best general combiner were found to be Parbhani kranti. The highest significant positive SCA was in the cross combination Arka Anamika $\times$ Parbkani ranti for fruit yield per plant. The cross combination Arka Anamika $\times$ Parbkani Kranti earliest flowering. Highest heterosis percentage for fruit yield per plant was observed in the cross combinations Parbkani Kranti $\times$ EC-305626 and Arka Anamika $\times$ Parbkani Kranti and for earliness it was observed in Arka Anamika × EC-305626. 
manufacture and for sizing paper (Khanna and Chakravarthi, 1949).

In an often cross pollinated crop like Okra, improvement in the past was based on selection of locally adopted populations. During recent years, exploitation of hybrid vigour and selection of parents based on combining ability have opened a new line of approach in crop improvement programmes. It helps the breeders to assess the combining ability effects of the parents and to select the best combinations for heterosis breeding. The knowledge of gene action and combining ability helps the breeders to identify the best combiners to exploit heterosis (or) to accumulate fixable genes through selection for the development of high yielding genotypes.

\section{Materials and Methods}

The present investigation was carried out at the experimental farm of Genetics and Plant Breeding Department, Faculty of Agriculture, Annamalai University. Six different Okra cultivars [Abelmoschus esculeutus (L). Moench] representing a wide range of variability in their economic traits were used for this present study. These genotypes are Arka Anamika (P1), Parbhani Kranti (P2), Pusa Sawani (P3), EC-112112 (P4), EC305626 (P5) and IC-128076 (P6).

The seeds of six parental genotypes were planted and the selfing was done in order to produce pure seeds and then the parents are crossed according to diallel mating design to produce 15 direct and reciprocal F1 hybrids. The parents and their $F_{1}$ hybrids were sown in a randomized block design with three replications. Each combination was sown in two rows of $4.5 \mathrm{M}$ length with a row spacing of $45 \mathrm{~cm}$ and plant to plant spacing of $30 \mathrm{~cm}$ were maintained. Recommended agronomic practices and need based plant production measures were judiciously followed.
Data were recorded for earliness, yield and yield related traits viz., days of seedling emergence (days) (DSE), days to first flowering (days) (DFF), number of primary branches per plant (NPBP), number of first fruiting node (NFFN), height of first fruiting node $(\mathrm{cm})(\mathrm{HFFN})$, plant height $(\mathrm{cm})(\mathrm{PH})$, days to first picking (days) (DFP), number of fruits per plant(NFP), fruit weight (gm) (FW) and fruit yield per plant (gm) (FY).

Data were subjected to analysis of variance in order to test the significance of differences among the parents and the hybrids, and sum of squares for genotypes was partitioned according to Griffing (1956b) Model I (fixed), Method I. Estimates of heterosis percentage were calculated according to Singh and Khanna (1975) and the significance of heterosis was tested using the formula suggested by Wynne et al., (1970).

\section{Results and Discussion}

\section{Genotypic variations}

Analysis of variance for all the genotypes are presented in Table 1. Mean squares of genotypes were found to be highly significant for all the traits studied. This provides the strong evidence for the presence of genetic variation among the selected genotypes from the reference population. The results are in harmony with Hazem et al., (2013), Srivastava et al., (2008).

\section{Mean performance}

Mean performance of F1 hybrids for earliness, yield and yield related traits are presented in the Table 2. Almost all the F1 hybrids showed considerable variation in their performance for all the traits studied. The cross combination AA $x$ PK $(\mathrm{P} 1 \times \mathrm{P} 2)$ recorded earliest flowering when compared to all the crosses, followed by AA $\times$ PS $(\mathrm{P} 1 \times \mathrm{P} 3)$. 
Table.2 Mean performance of F1 hybrids

\begin{tabular}{|c|c|c|c|c|c|c|c|c|c|c|c|}
\hline $\begin{array}{l}\text { S. } \\
\text { No. }\end{array}$ & Hybrids & DSE & DFF & NPBP & NFFN & HFFN & PH & DFP & NFP & FW & FY \\
\hline 1 & $\mathrm{P} 1 \times \mathrm{P} 2$ & 3.37 & 36.00 & 6.97 & 6.87 & 18.46 & 167.01 & 42.23 & 35.86 & 19.49 & 685.20 \\
\hline 2 & $\mathrm{P} 1 \times \mathrm{P} 3$ & 3.37 & 36.20 & 6.93 & 8.00 & 27.47 & 159.38 & 42.50 & 32.30 & 17.47 & 563.27 \\
\hline$\overline{3}$ & $\mathrm{P} 1 \times \mathrm{P} 4$ & 4.03 & 41.73 & 4.50 & 7.23 & 34.87 & 145.79 & 47.63 & 25.96 & 14.08 & 358.39 \\
\hline 4 & $\mathrm{P} 1 \times \mathrm{P} 5$ & 3.70 & 40.20 & 3.80 & 5.30 & 23.70 & 147.32 & 46.97 & 24.93 & 15.12 & 377.04 \\
\hline 5 & $\mathrm{P} 1 \times \mathrm{P} 6$ & 3.93 & 41.47 & 3.43 & 6.10 & 35.13 & 156.70 & 48.70 & 26.40 & 14.81 & 391.12 \\
\hline 6 & $\mathrm{P} 2 \times \mathrm{P} 3$ & 3.27 & 37.83 & 3.50 & 6.00 & 19.27 & 168.35 & 43.73 & 23.80 & 13.71 & 318.26 \\
\hline 7 & $\mathrm{P} 2 \times \mathrm{P} 4$ & 3.20 & 40.63 & 6.83 & 8.20 & 30.27 & 157.80 & 46.50 & 33.16 & 18.60 & 617.84 \\
\hline 8 & $\mathrm{P} 2 \times \mathrm{P} 5$ & 3.53 & 37.57 & 4.47 & 8.40 & 22.47 & 164.44 & 43.26 & 35.16 & 18.13 & 648.58 \\
\hline 9 & $\mathrm{P} 2 \times \mathrm{P} 6$ & 3.50 & 42.20 & 4.53 & 5.73 & 28.73 & 160.55 & 48.40 & 22.73 & 19.67 & 446.71 \\
\hline 10 & $\mathrm{P} 3 \times \mathrm{P} 4$ & 4.20 & 40.87 & 3.77 & 4.83 & 18.77 & 170.00 & 48.10 & 25.06 & 17.56 & 438.61 \\
\hline 11 & $\mathrm{P} 3 \times \mathrm{P} 5$ & 3.87 & 39.67 & 4.57 & 5.10 & 25.13 & 170.03 & 46.76 & 27.86 & 17.94 & 499.23 \\
\hline 12 & $\mathrm{P} 3 \times \mathrm{P} 6$ & 4.00 & 41.33 & 3.20 & 4.50 & 30.27 & 160.03 & 50.10 & 21.80 & 15.16 & 328.73 \\
\hline 13 & $\mathrm{P} 4 \times \mathrm{P} 5$ & 3.73 & 42.87 & 3.27 & 4.53 & 28.40 & 142.63 & 52.23 & 22.13 & 16.33 & 360.75 \\
\hline 14 & $\mathrm{P} 4 \times \mathrm{P} 6$ & 3.67 & 42.30 & 5.17 & 5.30 & 23.93 & 148.13 & 51.03 & 26.66 & 19.19 & 511.03 \\
\hline 15 & P5 $\times$ P6 & 3.73 & 40.70 & 3.67 & 4.50 & 31.63 & 165.53 & 46.83 & 19.76 & 16.20 & 319.74 \\
\hline
\end{tabular}

Table.3 Analysis of variance and mean sum of squares for combining ability analysis

\begin{tabular}{|l|c|c|c|c|c|c|c|c|c|c|c|}
\hline $\begin{array}{l}\text { Source of } \\
\text { Variation }\end{array}$ & DSE & DFF & NPBP & NFFN & HFF & PH & DFP & NFP & FW & FY \\
\hline GCA & $0.33 * *$ & $12.89 * *$ & $3.08 * *$ & $1.62 * *$ & $53.59 * *$ & $377.72 * *$ & $24.11 * *$ & $84.01 * *$ & $5.62 * *$ & $39321.00 * *$ \\
\hline SCA & $0.07 * *$ & $5.47 * *$ & $1.98 * *$ & $1.00 * *$ & $28.90 * *$ & $74.82 * *$ & $10.31 * *$ & $24.25 * *$ & $7.45 * *$ & $19792.67 * *$ \\
\hline GCA/SCA & 4.71 & 2.35 & 1.55 & 1.62 & 1.85 & 5.04 & 2.33 & 3.46 & 0.754 & 1.99 \\
\hline
\end{tabular}

** Significant at $1 \%$ level 
Table.4 Estimates of general combining ability effects for parents for all the traits

\begin{tabular}{|c|c|c|c|c|c|c|c|c|c|c|}
\hline Source of Variation & DSE & DFF & NPBP & NFFN & HFFN & PH & DFP & NFP & FW & FY \\
\hline P1 & -0.05 & $-0.90 * *$ & $0.59 * *$ & $0.38 * *$ & $2.47 * *$ & $-1.88 * *$ & $-1.00 * *$ & $1.53 * *$ & 0.18 & $31.67 * *$ \\
\hline $\mathbf{P 2}$ & $-0.23 * *$ & $-1.07 * *$ & $0.57 * *$ & 0.14 & $-2.23 * *$ & $5.88 * *$ & $-2.21 * *$ & $3.04 * *$ & $0.73 * *$ & $64.14 * *$ \\
\hline $\mathbf{P 3}$ & $-0.20 * *$ & -0.37 & $-0.24 * *$ & $0.16^{* *}$ & $-1.89 * *$ & $2.69 * *$ & $0.29 *$ & $-1.12 * *$ & $-1.23 * *$ & $-51.99 * *$ \\
\hline $\mathbf{P 4}$ & $-0.15 * *$ & 0.68 & $0.12 *$ & $-0.08 *$ & -0.24 & $-8.37 * *$ & $1.08 * *$ & $0.92 * *$ & -0.17 & $6.30 * *$ \\
\hline P5 & 0.06 & $-0.90 * *$ & $-0.43 * *$ & $-0.38 * *$ & $-0.77 * *$ & $-3.66 * *$ & 0.15 & 0.76 & $0.48 *$ & $9.60 * *$ \\
\hline P6 & $0.11 * *$ & $2.48 * *$ & $-0.60 * *$ & $-0.22 * *$ & $2.66 * *$ & $5.34 * *$ & $1.68 * *$ & $3.61 * *$ & 0.01 & $-59.72 * *$ \\
\hline SE & 0.03 & 0.17 & 0.04 & 0.04 & 0.29 & 0.81 & 0.12 & 0.23 & 0.17 & 2.23 \\
\hline
\end{tabular}

* Significant at 5\% level; ** Significant at $1 \%$ level

Table.5 Estimates of specific combining ability effects hybrids for all the traits

\begin{tabular}{|c|c|c|c|c|c|c|c|c|c|c|c|}
\hline S. No. & Hybrids & DSE & DFF & NPBP & NFFN & HFFN & PL & DFP & NFP & FW & FY \\
\hline 1 & $\mathrm{P} 1 \times \mathrm{P} 2$ & 0.01 & $-2.04 * *$ & $0.97 * *$ & $-0.21 * *$ & $-4.57 * *$ & $-5.68 * *$ & $-2.09 * *$ & $4.44 * *$ & 0.86 & $104.65 * *$ \\
\hline 2 & $\mathrm{P} 1 \times \mathrm{P} 3$ & $-0.31 * *$ & $-1.60 * *$ & $1.26^{* *}$ & $0.27 *$ & $4.51 * *$ & $3.88 * *$ & $-2.12 * *$ & $3.20 * *$ & 0.77 & $62.34 * *$ \\
\hline 3 & $\mathrm{P} 1 \times \mathrm{P} 4$ & $0.15^{* *}$ & $1.14 * *$ & $-0.62 * *$ & -0.08 & $4.43 * *$ & $-6.48 * *$ & $2.42 * *$ & $-5.59 * *$ & $-1.65 * *$ & $-105.67 * *$ \\
\hline 4 & $\mathrm{P} 1 \times \mathrm{P} 5$ & $-0.13^{*}$ & -0.76 & $-0.69 * *$ & $-0.64 * *$ & $-4.64 * *$ & $-4.78 * *$ & $-0.92 * *$ & $-1.57 * *$ & $-1.90 * *$ & -66.24 \\
\hline 5 & $\mathrm{P} 1 \times \mathrm{P} 6$ & $0.19 * *$ & -0.22 & $-0.50 * *$ & 0.07 & $1.35^{* *}$ & $-4.32 * *$ & -0.03 & $2.09 * *$ & $2.38 * *$ & $-35.97 * *$ \\
\hline 6 & $\mathrm{P} 2 \times \mathrm{P} 3$ & 0.09 & 0.14 & $-3.52 * *$ & 0.30 & $-1.32 *$ & -1.89 & $1.07 * *$ & $-6.44 * *$ & $-2.52 * *$ & $-176.65 * *$ \\
\hline 7 & $\mathrm{P} 2 \times \mathrm{P} 4$ & -0.08 & $2.73 * *$ & $1.66^{* *}$ & $-0.41 * *$ & $7.74 * *$ & -2.82 & $-1.50 * *$ & $2.89 * *$ & $1.53 * *$ & $81.74 * *$ \\
\hline 8 & $\mathrm{P} 2 \times \mathrm{P} 5$ & 0.11 & -0.76 & $0.90 * *$ & 0.06 & -0.97 & $10.10 * *$ & $-0.93 * *$ & $5.59 * *$ & $1.72 * *$ & $98.12 * *$ \\
\hline 9 & $\mathrm{P} 2 \times \mathrm{P} 6$ & 0.06 & $2.58 * *$ & $0.33^{* *}$ & $-0.28 * *$ & 0.36 & $5.25^{* *}$ & $2.42 * *$ & $-4.70 * *$ & $-1.54 * *$ & $-29.37 * *$ \\
\hline 10 & $\mathrm{P} 3 \times \mathrm{P} 4$ & 0.06 & $-2.36 * *$ & $-0.40 * *$ & $-0.97 * *$ & $-4.21 * *$ & $8.35^{* *}$ & $-2.70 * *$ & $1.07 * *$ & $1.25 * *$ & $32.56 * *$ \\
\hline 11 & $\mathrm{P} 3 \times \mathrm{P} 5$ & 0.05 & 0.11 & $0.53 * *$ & 0.20 & 0.40 & 1.23 & -0.48 & $1.09 * *$ & $1.01 *$ & $41.77 * *$ \\
\hline 12 & $\mathrm{P} 3 \times \mathrm{P} 6$ & $-0.13^{*}$ & -0.05 & $-0.55^{* *}$ & $0.68 * *$ & $2.87 * *$ & -3.36 & $1.39 * *$ & $-3.51 * *$ & -0.72 & -8.52 \\
\hline 13 & $\mathrm{P} 4 \times \mathrm{P} 5$ & 0.02 & 1.97 & $-1.97 * *$ & $-0.50 * *$ & $2.65 * *$ & -1.32 & $3.71 * *$ & $-3.74 * *$ & -0.74 & $-78.56 * *$ \\
\hline 14 & $\mathrm{P} 4 \times \mathrm{P} 6$ & 0.20 & $2.03 * *$ & $0.61 * *$ & $0.19 *$ & $-5.09 * *$ & 2.45 & $2.25 * *$ & -0.82 & $1.63 * *$ & $39.47 * *$ \\
\hline 15 & P5 × P6 & $0.13^{*}$ & -0.28 & $0.24 *$ & -0.05 & $4.78 * *$ & $6.70 * *$ & $-1.76^{* *}$ & -0.07 & -0.69 & $-18.08 * *$ \\
\hline SE & & 0.07 & 0.40 & 0.10 & 0.07 & 0.65 & 1.85 & 0.29 & 0.53 & 0.40 & 5.08 \\
\hline
\end{tabular}

* Significant at $5 \%$ level; ** Significant at $1 \%$ level 


\section{Int.J.Curr.Microbiol.App.Sci (2018) 7(5): 259-266}

Table.6 Estimates of heterosis over mid parents for all the traits

\begin{tabular}{|c|c|c|c|c|c|c|c|c|c|c|c|}
\hline S. No. & Hybrids & DSE & DFF & NPBP & NFFN & HFFN & PH & DFP & NFP & FW & FY \\
\hline 1 & $\mathrm{P} 1 \times \mathrm{P} 2$ & -2.88 & $11.66 * *$ & $68.42 * *$ & $66.66 * *$ & $-32.70 * *$ & 0.76 & $12.62 * *$ & $28.50 * *$ & $12.31 * *$ & $47.03 * *$ \\
\hline 2 & $\mathrm{P} 1 \times \mathrm{P} 3$ & $\begin{array}{c}- \\
20.16 * *\end{array}$ & $\begin{array}{c}- \\
16.32 * *\end{array}$ & $44.64 * *$ & $26.65 * *$ & -3.97 & 2.57 & $17.64 * *$ & $33.66 * *$ & 0.46 & $34.28 * *$ \\
\hline 3 & $\mathrm{P} 1 \times \mathrm{P} 4$ & $15.79 * *$ & -0.18 & -4.26 & $21.23 * *$ & $27.88 * *$ & -1.72 & -2.82 & $-5.06 *$ & -15.82 & $\begin{array}{c}- \\
19.73 * *\end{array}$ \\
\hline 4 & $\mathrm{P} 1 \times \mathrm{P} 5$ & $-8.26 *$ & $-2.72 * *$ & $-11.28 *$ & $-2.45 * *$ & $-19.35 *$ & -3.43 & $-5.15 * *$ & 12.06 & $-20.57 * *$ & $11.10^{-} * *$ \\
\hline 5 & $\mathrm{P} 1 \times \mathrm{P} 6$ & 3.06 & -0.18 & -15.23 & 12.27 & $10.35 * *$ & -3.18 & $-1.78 * *$ & $21.94 * *$ & $-19.65^{* *}$ & -2.77 \\
\hline 6 & $\mathrm{P} 2 \times \mathrm{P} 3$ & $\begin{array}{c}- \\
15.88 * *\end{array}$ & $-9.88 * *$ & $-8.70 *$ & $14.65 * *$ & -14.31 & 1.77 & $\begin{array}{c}- \\
11.71 * *\end{array}$ & $\begin{array}{c}- \\
11.74 * *\end{array}$ & -6.71 & $19.47 * *$ \\
\hline 7 & $\mathrm{P} 2 \times \mathrm{P} 4$ & 1.59 & 0.25 & $83.86 * *$ & $67.92 * *$ & $43.14^{* *}$ & -0.36 & $-0.96 * *$ & $10.01 * *$ & $32.56 * *$ & $46.34 * *$ \\
\hline 8 & $\mathrm{P} 2 \times \mathrm{P} 5$ & -4.50 & $-6.20 *$ & $35.35 * *$ & $93.10 * *$ & -3.44 & $1.14^{* *}$ & $-8.82 * *$ & $43.18 * *$ & $10.87 * *$ & $62.21 * *$ \\
\hline 9 & $\mathrm{P} 2 \times \mathrm{P} 6$ & 0.48 & 4.80 & $47.83 * *$ & $31.80 * *$ & 11.95 & $\begin{array}{c}- \\
6.59 * *\end{array}$ & 1.86 & -7.02 & $24.92 * *$ & $18.17 * *$ \\
\hline 10 & $\mathrm{P} 3 \times \mathrm{P} 4$ & 7.69 & $-4.78 * *$ & $-14.72 * *$ & $-23.08 * *$ & -15.95 & 14.87 & $-4.22 * *$ & -6.99 & $29.52 * *$ & $16.78 * *$ \\
\hline 11 & $\mathrm{P} 3 \times \mathrm{P} 5$ & $13.11 * *$ & $-6.52 *$ & 14.17 & $-11.30 * *$ & 2.79 & 11.70 & $-7.79 * *$ & $27.54 * *$ & 9.50 & $41.34 * *$ \\
\hline 12 & $\mathrm{P} 3 \times \mathrm{P} 6$ & $-5.51 * *$ & -3.09 & $-15.04 * *$ & $-21.74 * *$ & $12.73 * *$ & -0.92 & -1.35 & 2.59 & -3.91 & -0.80 \\
\hline 13 & $\mathrm{P} 4 \times \mathrm{P} 5$ & 0.45 & $4.60 * *$ & $-15.88 * *$ & $-16.05 * *$ & 22.88 & -1.75 & $8.52 * *$ & $\begin{array}{c}- \\
11.58 * *\end{array}$ & 3.86 & $-5.12 * *$ \\
\hline 14 & $\mathrm{P} 4 \times \mathrm{P} 6$ & $4.76 * *$ & $2.67 * *$ & $41.55^{* *}$ & $-1.85 * *$ & -6.19 & -4.10 & $5.88 * *$ & 9.14 & $29.96 * *$ & $42.59 * *$ \\
\hline 15 & $\mathrm{P} 5 \times \mathrm{P} 6$ & -7.82 & -0.04 & 13.40 & $-7.53 * *$ & $14.48 * *$ & $4.32 * *$ & -3.83 & 2.24 & -7.06 & -4.85 \\
\hline
\end{tabular}

* Significant at $5 \%$ level; ** Significant at $1 \%$ level 
Table.1 Analysis of variance for earliness, yield and yield related traits

\begin{tabular}{|l|l|l|l|l|}
\hline S. No. & Characters & df & MSS & 'F' value \\
\hline 1 & Days to seedling emergence & 35 & 0.35 & $10.56^{* *}$ \\
\hline $\mathbf{2}$ & Days to first flowering & 35 & 15.86 & $11.79^{* *}$ \\
\hline $\mathbf{3}$ & Number of primary branches per plant & 35 & 4.42 & $49.29^{* *}$ \\
\hline $\mathbf{4}$ & Number of first fruiting node & 35 & 5.78 & $85.91^{* *}$ \\
\hline $\mathbf{5}$ & Height of first fruiting node & 35 & 67.01 & $18.98^{* *}$ \\
\hline $\mathbf{6}$ & Plant height & 35 & 354.80 & $12.43^{* *}$ \\
\hline $\mathbf{7}$ & Days of first picking & 35 & 27.52 & $40.29^{* *}$ \\
\hline $\mathbf{8}$ & Number of fruits per plant & 35 & 72.99 & $31.53^{* *}$ \\
\hline $\mathbf{9}$ & Fruit weight & 35 & 13.82 & $10.45^{* *}$ \\
\hline 10 & Fruit yield per plant & 35 & 44474.89 & $207.76^{* *}$ \\
\hline
\end{tabular}

** Significant at $1 \%$ level

The cross combination AA $\times \mathrm{PK}(\mathrm{P} 1 \times \mathrm{P} 2)$ had high fruit yield (685.21gm) when compared with all the other crosses. Moreover this cross combination was best for number of primary branches per plant (6.97), days to first picking (42.23) and fruit weight (19.49). The results are in agreement with the earlier findings of Amarantha Reddy et al., (2013) and Medagam et al., (2012). Therefore, these promising crosses among the F1 hybrids can be used for further breeding studies to improve earliness, yield and yield related traits in Okra.

\section{Combining ability analysis}

The mean squares of general combining ability and specific combining ability for all the traits are presented in Table 3. The mean squares of GCA and SCA were highly significant for all the traits of interest. This trend indicated that both GCA and SCA were important in the inheritance of the traits of interest. However, the magnitudes of GCA were higher than SCA for all the traits indicating the predominance of the additive gene action and this trend can be exploited by resorting the simple pure line selection and/or pedigree selection. These results are in agreement with those previously reported by Senthil Kumar (2003) and Singh et al., (2011).

\section{GCA effects}

Estimates of general combining ability effects of the selected parents for all the traits are presented in Table 4. Accordingly, of all the selected genotypes, the genotype Parbhani Kranti (P2) was selected as the best general combiner for all the traits except plant height. The genotypes EC-112112 (P4) and EC305626 (P5) were good general combiners for the trait plant height. The best general combiner Parbhani Kranti and the other genotypes Arka Anamika (P1) and EC305626 (P5) were good combiners for earliness related traits. The genotype, Parbhani Kranti (P2) which exhibited useful general combining ability effects could be utilized in Okra breeding programme to improve earliness and yield related components. These results are in agreement with Hoque and Hazarilla (1996) and ElGendy Soher et al., (2012).

\section{SCA effects}

Estimates of specific combining ability effects for each cross combinations for earliness and yield component traits are shown in Table 5. The results revealed that the cross combination Arka Anamika $\times$ Pusa Sawani $(\mathrm{P} 1 \times \mathrm{P} 3)$, Arka Anamika $\times$ Parbhani Kranti $(\mathrm{P} 1 \times \mathrm{P} 2)$ and Pusa Sawani $\times$ EC-112112 $(\mathrm{P} 3$ 
$\times$ P4) showed desirable negative significant SCA for earliness. It is interesting to note that these cross combinations possessed good $\times$ poor, good $\times$ good and poor $\times$ poor general combiner for days for first flowering which accounts for earliness. With respect to fruit yield as it is the main concern for the breeders the cross combination Arka Anamika $\times$ Parbhani Kranti $(\mathrm{P} 1 \times \mathrm{P} 2)$ recorded desirable positive significant SCA. The parents of this cross combinations possess good $\times$ good combining ability. Similarly the next cross combinations Parbhani Kranti $\times$ EC-305626 $(\mathrm{P} 2 \times$ P5) and Pusa Sawani $\times$ EC-112112 (P3 $\times \mathrm{P} 4)$ also possess poor $\mathrm{x}$ good general combiners. When concerned with yield components the parents of the best cross combinations also showed good $\times$ good, poor $\mathrm{x}$ good and poor $\times$ poor combining ability. Therefore, it is not necessary that parents having estimates of high GCA effects would also give high estimates of SCA effects in their respective cross combinations. These results revealed the important role played by the non-additive gene action in the inheritance of all the traits of our interest. Similar results were also reported by Hazem et al., (2013), Senthil Kumar (2003), Reddy et al., (2012) and Wammanda et al., (2010).

\section{Estimates of Heterosis}

Estimates of heterosis over mid parents for all traits are presented in Table 6. When concerned with the earliness the cross combination Arka Anamika $\times$ EC-305626 (P1 $\times$ P5) showed negative heterosis over its mid parent (-2.72) and almost all the crosses which exhibited earliness ranged from $-2.72 \%$ to $-16.32 \%$ respectively. When concerned with the fruit yield per plant the cross combination Parbhani Kranti $\times$ EC-305626 $(\mathrm{P} 2 \times \mathrm{P} 5)$ recorded highest positive heterosis followed by the crosses Arka Anamika $\times$ Parbhani Kranti $(\mathrm{P} 1 \times \mathrm{P} 2)$ and Parbhani Kranti $\times$ EC-112112 $(\mathrm{P} 2 \times \mathrm{P} 4)$ and the heterosis value ranged from $16.78 \%$ to $62.21 \%$ for all the crosses. With respect to the yield related traits almost all the traits exhibited heterosis over its mid parent and it ranged from $83.36 \%$ to $35.35 \%$ for number of primary branches per plant, $93.10 \%$ to $14.65 \%$ for number of first fruiting node and $32.56 \%$ to $10.87 \%$ for fruit weight. In general, these results indicate that most of the crosses were significantly earlier and higher yielding than their mid parents. This suggests the importance of non-additive gene action in the inheritance of all the traits in Okra. The results are in agreement with those previously reported by Hazem et al., (2013), Jaiprakashnarayan et al., (2008). In general the study reveals the importance of the cross combination AA $\times$ PK (P1 x P2) as it possess high mean, high SCA and heterosis. This cross combination and its parents involved could be very effective in developing high yielding genotypes with earliness in okra breeding.

\section{References}

Amaranatha Reddy, M., O. Sridevi, P.M. Salimath and H.L. Nadal. 2013. Combining ability for yield and yield components through diallel analysis in Okra (Abelmoschus esculentus (L.) Moench). IOSR J. Agric. Veterinary Sci., 5(2): $1-6$

Anonymous. 2009. Rep. Centre for monitoring Indian Economy and Agric. January 2009, pp. 305-306.

Benjamin, H.B., H.K. Ehrig and D.A. Roth. 1951a. The use of Okra as a plasma replacement. Rev. Canadienne. Biol., 10: 215-220.

Cobley, L.S. and W. M. Steele. 1976. An introduction to the botany of tropical crops. $2^{\text {nd }}$ edition, Longman, London. Pp. 146-148.

EI-Gendy, E.A. Soher, H.A. Obiadalla - Ali, E.A. Ibrahim and M.H.Z. Eldekashy. 2012. Combining ability and nature of 
gene action in Okra (Abelmoschus esculentus (L.) Moench). J. Agric. Chem. Biotechnol. Mansoura Univ., 3(7): 195205.

Griffing, B. 1956b. Concept of general and specific combining ability in relation to diallel crossing systems. Australian J. Biol. Sci., 9: 463-493.

Hazem A. Obiudalla- Ali, M.H.Z. Eldekashy and A.A. Helaly. 2013. Combining ability and heterosis for yield and its components in some cultivars of Okra (Abelmoschus esculentus (L.) Moench). American Eurasian J. Agric. Environ. Sci. 13(2): 162-167.

Hoque, M. and G.N. Hazarika. 1996. Genetic architecture of yield and yield contributing characters in Okra (Abelmoschus esculentus (L.) Moench). J. Agric. Sci. Soc., North East India. 9(1): $72-75$.

Indian Horticulture Database -2011 (http://agriexchange.apeda.gov.in/Market \%20Profile/one/OKRA.aspx)

Jaiprakashnarayan, R.P., S.K. Prashanth, R. Mulge and M.B. Madalageri. 2008. Study on the heterosis and combining ability of earliness and yield parameters in Okra (Abelmoschus esculentus (L.) Moench). The Asian J. Horti. 3: 136-141.

Khanna, K.C. and A.S. Chakravarthi. 1949. Studies in the clarification of sugarcane juice in gur manufacture. Indian J. Agric. Sci. 19: 137-161.

Medagam, T.R., H. Kadiyara, G. Mutyala and B. Hameedunnisa. 2012. Heterosis for yield and yield components in Okra (Abelmoschus esculentus (L.) Moench). Chilean J. Agric. Res., 72(3): 316-325.

Reddy, M.T., K. Haribabu, M. Ganesh, K.C. Reddy, H. Begum, R.S.K. Reddy and J.D.
Babu. 2012. Genetic analysis for yield and its components in Okra (Abelmoschus esculentus (L.) Moench). Songklanakarin J. Sci., Technol. 34(2): 133-141.

Savello, P., F.W. Martin and J.M. Hill. 1980. Nutritional composition of Okra seed meal. Agric. Food Chem., 28: 1163-1166.

Senthil Kumar, N. 2003. Studies on genetic architecture of yield and yield component characters in Okra (Ablenmoschus esculentus (L.) Moench). Unpublished Ph.D. Thesis, Ann. Univ., India.

Singh, B., S.K. Singh and K.V. Singh. 2011. Study on combining ability in Okra (Abelmoschus esculentus (L.) Moench). Indian J. Horti. 67: 154-159.

Singh, S.K. and R. Khanna. 1975. Physiological, biochemical basis of heterosis. Adv. Agron., 27: 123-174.

Srivastava, M.K., S. Kumar and A.K. Pal. 2008. Studies on combining ability in Okra through diallel analysis. Indian J. Horti., 65(1): 120-128.

Tomoda, M., K. Shimada, Y. Saito and M. Sugi. 1980. Plant mucilages: 26, Isolation and structural features of a mucilage, Okramucilage $\mathrm{F}$, from the immature fruits of Abelmoschus esculentus (L.) Moench. Chem. Pharm. Bull., 28: 2933-2940.

Wammanda, D.T., A.M. Kadams and P.M. Jonah. 2010. Combining ability analysis and heterosis in a dialle cross of Okra (Abelmoschus esculentus (L.) Moench). Afr. J. Agric. Res. 5(16): 2108-2115.

Woodruff, J.G. 1927. Okra. Georgia. Exp. Stn. Bull., 145: 164-165.

Wynne, J.C., D.A. Emery and P.W. Rice. 1970. Combining ability estimates of Arachis hypogaea L. II Field performance of F1 hybrids, Crop Sci., 10: 713-715.

\section{How to cite this article:}

Eswaran, R. and Anbanandan, V. 2018. Combining Ability and Heterosis for Earliness, Yield and Its Component Traits in Okra (Abelmoschus esculentus L. Moench). Int.J.Curr.Microbiol.App.Sci. 7(05): 259-266. doi: https://doi.org/10.20546/ijcmas.2018.705.034 